\title{
Pengaruh Content Marketing Dan Lifestyle Terhadap Keputusan Pembelian Pada Usaha Kecil Menengah Di Media Sosial
}

\author{
Isra Ul Huda ${ }^{1}$ \\ Email: israulhuda83@gmail.com \\ Anthonius J. Karsudjono ${ }^{2}$ \\ Email: tonimbbm@yahoo.com \\ Ryan Darmawan ${ }^{3}$ \\ Email: lastarmy55@gmail.com
}

\begin{abstract}
Abstrak:
Penelitian ini bertujuan Untuk mengetahui dan menganalisa pengaruh Content Marketing dan juga Lifestyle Terhadap Keputusan Pembelian Pada Usaha Kecil Menengah Di Media Sosial. Penelitian ini menggunakan metode analisa data kuantitatif, teknik analisis adalah analisis regresi linier berganda. Alasan pemilihan menggunakan metode tersebut ini adalah adanya pengujian antarvariabel bebas terhadap variabel terikat. Hasil analisis yang dilakukan menyatakan bahwa Content Marketing tidak berpengaruh signifikan Terhadap Keputusan Pembelian Pada Usaha Kecil Menengah Di Media Sosial, sedangkan Lifestyle berpengaruh signifikan Terhadap Keputusan Pembelian Pada Usaha Kecil Menengah Di Media Sosial
\end{abstract}

Kata Kunci: Content Marketing, Lifestyle, Keputusan Pembelian 


\section{PENDAHULUAN}

Virus corona baru merebak di Tanah Air, pemerintah awalnya mengumumkan kasus pertama positif covid-19 di Indonesia pada Senin tanggal 2 Maret 2020. Virus corona memukul berbagai sudut ekonomi. Usaha mikro, kecil, dan menengah (UMKM) justru menjadi sektor paling rentan kena hantaman pandemi virus corona. Sektor ini disebut para ekonom tak bisa lagi menjadi penyangga perekonomian seperti saat krisis ekonomi dan keuangan 1998 dan 2008.

Menteri Koperasi dan UKM Teten Masduki mengatakan, pihaknya menyadari bahwa penyebaran Covid-19 berpotensi berdampak secara ekonomi terhadap keberlangsungan koperasi, usaha mikro, kecil, dan menengah. "Kami sangat memahami bahwa ini akan berdampak signifikan bagi kelangsungan usaha KUMKM. Sumber : Investor Daily (2020).

Berdasarkan data dapat diketahui Usaha Mikro, Kecil dan Menengah (UMKM) pada tahun 2017 berjumlah 62.922.617 pada 2018 mengalami peningkatan signifikan dengan jumlah 64.194.057 mengalami perkembangan sebesar 2,02\%. Kemudian Usaha Mikro, Kecil dan Menengah (UMKM) pada tahun Kepuasan pelanggan merupakan salah satu kunci keberhasilan suatu bisnis. Banyak kegagalan bisnis terjadi karena pelanggan dikecewakan sehingga mereka mencari alternatif ke produk sejenis lainnya. Oleh karena itu hampir setiap perusahaan saat ini menyadari pentingnya arti pelanggan bagi perusahaan dan berupaya keras untuk dapat memberikan kepuasan kepada pelanggan. Karena dengan pelanggan yang puas, keuntungan akan datang dengan sendirinya, seperti dikemukakan Paul Allaire (Xerox),"Jika kami melakukan apa yang baik bagi pelanggan, bagian pasar dan laba operasi kami akan datang dengan sendirinya".

Guna menghadapi berbagai tantangan bisnis di tengah wabah Corona, UKM perlu meracik strategi yang tepat supaya usahanya tak terkena imbas negatif kelesuan ekonomi. Salah satunya dengan memanfaatkan teknologi untuk meningkatkan keputusan pembelian. Keputusan pembelian adalah bagian dari perilaku konsumen. Dengan adanya perilaku konsumen yaitu keinginan dan kebutuhan untuk membeli produk atau jasa tertentu maka akan terciptanya keputusan konsumen untuk membeli. Menurut PeterOlson dalam (Mulyadi Nitisusastro 2012:195) menegaskan bahwa pengambilan keputusan konsumen merupakan proses interaksi antara sikap afektif, sikap kognitif, sikap behavioral dengan faktor lingkungan dengan mana manusia melakukan pertukaran dalam semua aspek kehidupannya.

Herni Tri Hartanti (2018) dengan hasil penelitian Content marketing di Instagram memiliki pengaruh signifikan terhadap keputusan pembelian. Perkembangan era digital saat ini telah mempengaruhi dunia pemasaran. Dimana setiap perusahaan saling berkompetisi untuk menunjukan siapa yang terbaik. Dimana saat ini dalam membentuk promosi yang baik sudah tidak lagi menggunakan advertising pada umumnya namun lebih menggunakan pada content marketing.

Content marketing sendiri merupakan suatu strategi pemasaran dimana kita merencanakan, mendistribusikan, dan membuat konten yang mampu menarik audiens yang tepat sasaran, lalu mendorong mereka menjadi customer. Dimana content 
marketing memiliki 2 tujuan yang penting yaitu menarik audiens serta mendorong audiens menjadi customer. Content marketing dapat menarik konsumen dengan menciptakan suatu engagement antara customer (Kucuk \& Krishnamhurty, 2007). Yang membedakan content marketing dengan hal lainnya adalah jika iklan promosi hanya berisi tentang promosi suatu produk saja. Namun content marketing digunakan untuk mempromosikan brand dengan cara mendistribusikan konten yang bermanfaat bagi pengunjung (Halvorson K, 2010).

Selain content marketing yang mempengaruhi keputusan pembeliah adalah Lifestyle. Gt. Rina Fariany (2016) dalam hasil penelitiannya menunjukkan bahwa lifestyle berupa activity, interest dan opinion berpengaruh terhadap keputusan pembelian. Sumarwan (2015) menyatakan bahwa gaya hidup didefinisikan sebagai pola di mana orang hidup dan menggunakan uang dan waktunya. Kemudian Engel et al (1994) menyatakan bahwa gaya hidup didefinisikan sebagai pola di mana orang hidup dan menghabiskan waktu serta uang. Konsep gaya hidup konsumen cukup berbeda dengan kepribadian. Gaya hidup (lifestyle) menunjukkan bagaimana orang hidup, bagaimana mereka membelanjakan uangnya, dan bagaimana mereka mengalokasikan waktu mereka.

\section{TINJAUAN PUSTAKA}

\section{Content Marketing}

Di era digital ini isi konten dari sebuah pesan sangatlah penting. Content marketing sendiri merupakan suatu strategi pemasaran dimana kita merencanakan, mendistribusikan, dan membuat konten yang mampu menarik audiens yang tepat sasaran, lalu mendorong mereka menjadi customer. Dimana content marketing memiliki 2 tujuan yang penting yaitu menarik audiens serta mendorong audiens menjadi customer. Content marketing dapat menarik konsumen dengan menciptakan suatu engagement antara customer ( Kucuk\& Krishnamhurty, 2007) melalui sharing content dan kreatifitas suatu isi konten dengan isi yang relevan, penuh arti, bernilai dan mampu menjadi inspirasi bagi calon customer suatu perusahaan.Karr (2016:9) mengidentifikasi dimensi yang harus perusahaan evaluasi ketika menghasilkan sebuah konten, diantaranya yaitu:

a. Reader Cognition. Audiensi dari pembuat konten selalu beragam dalam cara mereka mencerna konten, maka keragaman dalam konten yang dibuat termasuk di dalamnya interaksi visual, suara, dan kinestetik diperlukan untuk menjangkau semua pembacanya.

b. Sharing Motivation. Berbagi informasi sangat penting dalam dunia sosial untuk memperluas jangkauan perusahaan ke audiensi yang lebih luas dan relevan. Ada alasan khusus mengapa audiensi sebuah konten akan berbagi konten yang mereka baca atau lihat. Audiensi berbagi konten untuk meningkatkan nilai dirinya bagi orang lain, menciptakan identitas diri secara daring, melibatkan diri dalam komunitasnya, memperluas jaringan mereka, dan membawa kesadaran terhadap suatu kejadian tertentu. 
c. Persuasion. Hal ini merujuk pada bagaimana perusahaan membujuk audiensi konten mereka untuk berpindah dari satu pilihan ke pilihan berikutnya dalam proses mereka menjadi customer.

d. Decision Making. Setiap individu dipengaruhi secara berbeda-beda dari berbagai "kriteria pendukung" ketika membuat sebuah keputusan. Kepercayaan, fakta, emosi, dan efisiensi semuanya memainkan peran, dengan kombinasi di dalamnya. Oleh karena itu, dengan memiliki konten yang seimbang dengan memperhatikan "kriteria pendukung" tersebut merupakan praktik terbaik pada setiap bagian konten yang dihasilkan perusahaan.

Factors. Saat menulis konten, perusahaan sering tidak memikirkan faktorfaktor lain yang memengaruhi orang ketiga di luar konten yang didiskusikan oleh audiensinya. Setiap keputusan yang perusahaan buat tidak hanya dievaluasi secara pribadi oleh audiensi tetapi ada pengaruh teman, keluarga, dan lingkungan sosialnya

\section{Lifestyle}

Nugroho, (2003) mendenifisikan gaya hidup secara luas sebagai cara hidup yang diidentifikasi oleh bagaimana orang menghabiskan waktu mereka (aktifitas) apa yang mereka anggap penting dalam lingkungannya (keterkaitan) dan apa yang mereka perkirakan tentang diri mereka sendiri dan dunia sekitarnya. Amstrong (dalam Nugraheni, 2003) menyatakan bahwa faktor-faktor yang mempengaruhi gaya hidup seseorang ada 2 faktor yaitu faktor yang berasal dari dalam diri individu (internal) dan faktor yang berasal dari luar (eksternal).

a. Faktor internal terdiri dari : 1. Sikap 2. Pengalaman dan pengamatan 3. Kepribadian 4. Konsep diri 5. Motif 6. Persepsi

b. Faktor eksternal terdiri dari : 1. Kelompok referensi 2. Keluarga 3. Kelas sosial 4. Kebudayaan

\section{Keputusan Pembelian}

Menurut Kotler dan Keller yang dialih bahasakan oleh Tjiptono (2012) keputusan pembelian sebagai tahap keputusan dimana konsumen secara aktual melakukan pembelian suatu produk.Indikator keputusan pembelian menurut Kotler dan Keller yang dialih bahasakan oleh Tjiptono (2012:184) menjelaskannya bahwa keputusan konsumen untuk melakukan pembelian suatu produk meliputi enam sub keputusan sebagai berikut:
a. Pilihan produk
b. Pilihan merek
c. Pilihan penyalur
d. Waktu pembelian.
e. Jumlah pembelian 


\section{METODE PENELITIAN Jenis Penelitian}

Jenis penelitian kuantitatif adalah untuk mengetahui pengaruh dari variabel bebas terhadap variabel terikat (Sugiyono, 2010). Pengumpulan data dilakukan agar peneliti dapat memperoleh informasi maupun masalah yang dibutuhkan sebagai tujuan penelitian. Pengumpulan data dengan kuesioner, yaitu dengan cara menyampaikan kuisioner kepada responden untuk mendapatkan data sesuai dengan tujuan penelitian. Teknik analisis data menggunakan regresi linear berganda untuk menguji hipotesis dengan alat analisis statistik berupa software SPSS Versi 21. Alasan pemilihan menggunakan analisis regresi linear berganda ini adalah disesuaikan dengan tujuan penelitian ini yaitu selain untuk menguji pengaruh variabel terikat terhadap variabel bebas. Pengujian dianggap layak atau bebas dari pelanggaran asumsi klasik agar hasil pengujian dapat diinterprestasikan dengan tepat

\section{KERANGKA KONSEP PENELITIAN}

Kerangka konseptual model dalam penelitian ini disusun berdasarkan kajian teoritis maupun empiris adalah sebagai berikut :

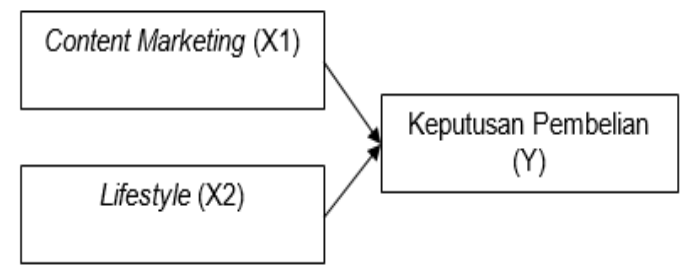

Gambar 1, Kerangka Konseptual Model Penelitian

\section{HIPOTESIS PENELITIAN}

Berdasarkan kerangka konseptual tersebut, maka dapat disusun hipotesis penelitian sebagai berikut :

1. Content Marketing memiliki pengaruh Terhadap Keputusan Pembelian Pada Usaha Kecil Menengah Di Media Sosial

2. Lifestyle memiliki pengaruh Terhadap Keputusan Pembelian Pada Usaha Kecil Menengah Di Media Sosial. 


\section{HASIL PENELITIAN DAN PEMBAHASAN}

\section{Hasil Analisis Regresi Linier Berganda}

Analisis yang digunakan dalam penelitian ini adalah regresi linier berganda. Model regresi yang digunakan adalah sebagai berikut :

Tabel 2

\section{Analisis Regresi Linier Berganda}

\begin{tabular}{|l|r|r|r|r|}
\hline \multirow{2}{*}{ Model } & \multicolumn{2}{|c|}{$\begin{array}{c}\text { Unstandardized } \\
\text { Coefficients }\end{array}$} & \multirow{2}{*}{ Sig. } \\
\cline { 2 - 3 } & \multicolumn{1}{|c|}{$\mathrm{B}$} & Std. Error & & \\
\hline (Constant & 9.217 & 2.593 & 3.555 & .001 \\
${ }^{3}{ }^{\mathrm{X} 1}$ & & & & \\
$\mathrm{X} 2$ & .077 & .063 & 1.230 & .222 \\
& .780 & .069 & 11.241 & .000 \\
\hline
\end{tabular}

Sumber : Diolah Penulis2020

$\mathrm{Y}=9.217+0,077 \mathrm{X}_{1}+0,780 \mathrm{X}_{2}+\mathrm{e}$

Keterangan:

Dari persamaan tersebut dapat diketahui bahwa :

1. Nilai koefisien regresi variabel Content marketing 0,077 adalah positif, dengan demikian dapat disimpulkan adanya hubungan searah antara variabel bebas dan variabel terikat. Hal ini berarti bahwa setiap peningkatan Content marketing sebesar 1 kali maka Keputusan Pembelian akan meningkat sebesar 0,077atau 77\% dengan asumsi variabel yang lain konstan

2. Nilai koefisien regresi variabel Lifestyle 0,780 adalah positif, dengan demikian dapat disimpulkan adanya hubungan searah antara variabel bebas dan variabel terikat. Hal ini berarti bahwa setiap peningkatan Lifestyle sebesar 1 kali maka Keputusan Pembelian akan meningkat sebesar 0,780 atau 78\% dengan asumsi variabel yang lain konstan

\section{Uji Hipotesis Secara parsial (Uji Statistik t)}

Berdasarkan hasil uji t yang tercantum pada tabel diatas, maka dapat dilihat bahwa:

a. X1 didapatkan nilai sig. $=0,222$ (Nilai Sig. $>0,05$ ) dan memiliki nilai t-hitung sebesar 1.230, lebih kecil dari nilai t-tabel sebesar 1.65993 artinya tidak berpengaruh signifikan terhadap variabel $Y$. Dengan demikian Content marketing tidak 
berpengaruh signifikan terhadap Keputusan Pembelian Pada Usaha Kecil Menengah Di Media Sosial.

b. X2 didapatkan nilai sig. $=0,000$ (Nilai Sig. $<0,05$ ) dan memiliki nilai t-hitung sebesar 11.241, lebih besar dari nilai t-tabel sebesar 1.65993 artinya berpengaruh signifikan terhadap variabel Y. Dengan demikian Lifestyle berpengaruh signifikan terhadap Keputusan Pembelian Pada Usaha Kecil Menengah Di Media Sosial.

\section{Pembahasan}

1. Pengaruh Content Marketing Terhadap Keputusan Pembelian Pada Usaha Kecil Menengah Di Media Sosial

Berdasarkan hasil pengujian diketahui nilai t-hitung sebesar 1.230, lebih kecil dari nilai t-tabel sebesar 1.65993. Artinya Content marketing tidak berpengaruh signifikan terhadap Keputusan Pembelian Pada Usaha Kecil Menengah Di Media Sosial. Hal ini menunjukkan bahwa Content Marketing yang secara langsung belum mampu meningkatkan Keputusan Pembelian Usaha Kecil Menengah Di Media Sosial.

Penelitian ini membuktikan bahwa semakin baik content marketing yang dilakukan Usaha Kecil Menengah Di Media Sosial belum memberikan dampak secara langsung dan signifikan pada terciptanya Keputusan Pembelian Usaha Kecil Menengah Di Media Sosial. Menurut pendapat Kucuk\& Krishnamhurty (2007) Dimana content marketing memiliki 2 tujuan yang penting yaitu menarik audiens serta mendorong audiens menjadi customer. Akan tetapi konsep Content Marketing yang dijalankan oleh Usaha Kecil Menengah Di Media Sosial masih belum maksimal, sehingga konsep Content Marketing untuk dijadikan media promosi melalui sosial media sebagais arana pemasaran dan membangun hubungan dengan pelanggan dan calon pelanggan untuk dapat menarik konsumen serta mendorong konsumen masih belum berjalan dengan baik.

\section{Pengaruh Lifestyle Terhadap Keputusan Pembelian Pada Usaha Kecil Menengah Di Media Sosial}

Berdasarkan hasil pengujian diketahui memiliki nilai t-hitung sebesar 11.241, lebih besar dari nilai t-tabel sebesar 1.65993. Artinya Lifestyle berpengaruh signifikan terhadap Keputusan Pembelian Pada Usaha Kecil Menengah Di Media Sosial. Hal ini menunjukkan bahwa Lifestyle yang secara langsung sangat mampu meningkatkan Keputusan Pembelian Usaha Kecil Menengah Di Media Sosial.

Penelitian ini membuktikan setiap terjadi peningkatan gaya hidup akan meningkatkan keputusan pembelian konsumen sebesar 78\%. Menurut Nugroho, (2003) gaya hidup secara luas sebagai cara hidup yang diidentifikasi oleh bagaimana orang menghabiskan waktu mereka (aktifitas) apa yang mereka anggap 
penting dalam lingkungannya dan apa yang mereka perkirakan tentang diri mereka sendiri dan dunia sekitarnya.

Dapat disimpulkan bahwa gaya hidup seseorang di dunia yang ekspresikan dalam minat dan opininya dapat memberikan dampak yang signifikan terhadap keputusan berbelanja. Hal itu terjadi karena perubahan zaman yang semakin modern sehingga orang-orang berlomba untuk mengikuti trend gaya hidup dengan berbelanja online terutama di media

\section{KESIMPULAN}

Berdasarkan hasil penelitian, maka dapat disimpulkan sebagai berikut :

1. Content marketing tidak berpengaruh signifikan terhadap Keputusan Pembelian Pada Usaha Kecil Menengah Di Media Sosial. Hal ini menunjukkan bahwa Content Marketing yang secara langsung belum mampu meningkatkan Keputusan Pembelian Usaha Kecil Menengah Di Media Sosial

2. Lifestyle berpengaruh signifikan terhadap Keputusan Pembelian Pada Usaha Kecil Menengah Di Media Sosial. Hal ini menunjukkan bahwa Lifestyle yang secara langsung sangat mampu meningkatkan Keputusan Pembelian Usaha Kecil Menengah Di Media Sosial

\section{DAFTAR PUSTAKA}

Buchari Alma, (2011), Manajemen Pemasaran dan Pemasaran Jasa, Cetakan Kesembelian, Alfabeth, Bandung

Engel, J. F., G. Blackwell, dan P. W. Miniard. 1994. Perilaku Konsumen . Jilid 1. Binarupa Aksara, Jakarta

Fandy Tjiptono. 2012. Strategi Pemasaran, ed. 3, Yogyakarta, Andi.

Gt. Rina Fariany (2016, Pengaruh Lifestyle Terhadap Keputusan Pembelian Produk Fashion Secara Online

Hartanti, Herni Tri (2018) Pengaruh Dimensi-Dimensi Content Marketing Terhadap Keputusan Pembelian Konsumen (Studi Pada Akun Instagram@GIGIEATCAKE)

Halvorson, K. (2010). Content Strategy For The Web. New Riders : Berkeley

Investor Daily (2020)

J. Setiadi, Nugroho, SE., MM., 2003, "Perilaku Konsumen Konsep dan Implikasi untuk Strategi dan Penelitian Pemasaran". Jakarta: Kencana

Johan Ardi Limandono, Diah Dharmayanti, Pengaruh Content Marketing Dan Event Marketing Terhadap Customer Engagement Dengan Sosial Media Marketing Sebagai Variabel Moderasi Di Pakuwon City

Karr, D. (2016). How To Map Your Content To Unpredictable Customer Journeys. Meltwater Outside Insight . Meltwater 
Kucuk, S. U., \& Krishnamurty, S. (2007, Februari). An Analysis of Consumer Power On The Internet.Technovation, 27, $47-56$.

Nitisusastro, Mulyadi. (2012). Perilaku Konsumen Dalam Perspektif Kewirausahaan. Bandung : Alfabeta

Nugraheni, P.N.A. 2003. Perbedaan Kecenderungan Gaya Hidup Hedonis Pada Remaja Ditinjau dari Lokasi Tempat Tinggal. Skripsi (tidak diterbitkan). Surakarta : Fakultas Psikologi UMS

Sugiyono. 2010. Metode Penelitian Pendidikan Pendekatan Kuantitatif, kualitatif, dan R\&D. Bandung: Alfabeta

Sumarwan, Ujang. 2015. Perilaku Konsumen Teori Penerapannya Dalam Pemasaran Edisi Kedua. Cetakan Ketiga. Bogor: Penerbit Ghalia Indonesia 